\title{
Leukaemia cutis
}

\section{*Dillip Kumar Das ${ }^{1}$, Suprabha Shukla ${ }^{2}$}

Sri Lanka Journal of Child Health, 2016; 45(2):134-136

DOI: http://dx.doi.org/10.4038/sljch.v45i2.7921

(Key words: Leukaemia cutis, acute lymphoblastic leukaemia)

\section{Introduction}

Leukaemia cutis (LC) is defined as cutaneous infiltration by neoplastic leucocytes (myeloid or lymphoid), resulting in clinically identifiable cutaneous lesions ${ }^{1}$. LC has been described in patients with acute myeloid leukaemia (AML), chronic myeloproliferative disease and myelodysplastic syndromes $^{2}$. We report a case of LC with skin lesions without systemic features.

\section{Case report}

A 14 year old, previously healthy girl presented with multiple erythematous, hyperpigmented, plaques and nodules over the face for 4 weeks (Figure 1).

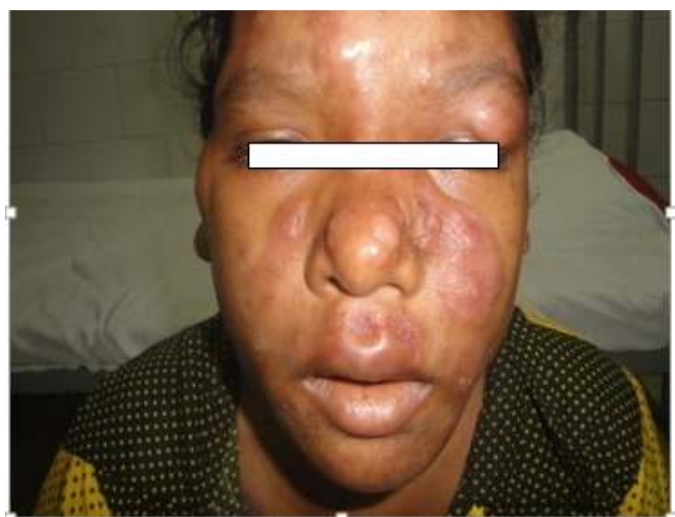

Figure 1: Face of patient with erythematous, hyperpigmented, plaques and nodules

*Permission given by parents to publish photograph

$\overline{{ }^{1} \text { Assistant Professor, Paediatrics, Hi Tech Medical }}$ College, Bhubaneswar, Odisha, India, ${ }^{2}$ Senior Resident, Department of Paediatrics, SCB Medical College, Cuttack, Odisha, India

*Correspondence: dr.dillipdas@gmail.com

(Received on 14 January 2015: Accepted after revision on 20 February 2015)

The authors declare that there are no conflicts of interest

Personal funding was used for this project.

Open Access Article published under the Creative

Commons Attribution CC-BY (CC)
She had been treated with topical steroids and antihistamines for above complaints. There was cervical lymphadenopathy but no pallor or hepatosplenomegaly. She also had low grade fever for 10 days. A complete blood count and peripheral blood smear did not show any significant findings. Based on physical examination cutaneous leukaemia was suspected. Biopsy was performed from a suspicious skin lesion on face and the histopathology report confirmed LC. The section showed the leukaemic cells forming nodular aggregate with a sheet like pattern separated from epidermis by a clear zone of upper dermis. The epidermis was focally thinned out but did not show any evidence of tumour infiltration. The tumour cells were monotonous with round hyperchromatic nucleus, inconspicuous nucleolus and scanty cytoplasm. Occasional mitotic figures were also seen (Figure 2).

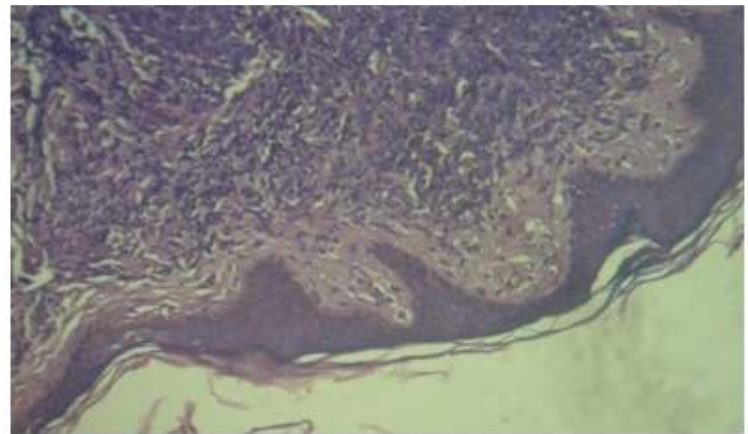

Figure 2: Haematoxylin and eosin stain (200X): microphotograph shows leukaemic cells in a nodular aggregate in lower dermis with clear zone of separation from epidermis

A bone marrow aspirate confirmed precursor B-cell acute lymphoblastic leukaemia (ALL) with $25 \%$ blast cells. On immunophenotypic analysis, the neoplastic cells were positive for CD45, CD10, CD19, CD22, HLA-DR. Cytogenetic studies showed normal 46XX karyotype and ALL chromosomal translocations were negative. Chest $\mathrm{x}$-ray did not show enlarged thymus. Cerebrospinal fluid (CSF) study showed no blast cells. Induction therapy was started immediately using protocol ALL ICBFM 2009. On the 20th day of induction chemotherapy, the soft tissue and skin lesions had almost completely regressed. 


\section{Discussion}

LC occurs in $10-15 \%$ of patients with AML and less frequently in chronic myeloproliferative disease ${ }^{3}$. Of infants with congenital leukaemia $25-30 \%$ develop skin involvement ${ }^{4}$. Congenital acute leukaemia, most frequently associated with $\mathrm{LC}$ is $\mathrm{AML}^{5}$. Lesions of LC are usually single or multiple, violaceous, redbrown, or haemorrhagic papules, nodules and plaques of varying sizes. Legs are involved most commonly, followed by arms, back, chest, scalp, and face. Leukaemic infiltration tends to preferentially occur at sites of previous or concomitant inflammation ${ }^{6}$.

Most cases of LC occur after a diagnosis of systemic leukaemia has been established. In one third cases, concomitant involvement of skin and systemic leukaemia has been observed, and in less than $10 \%$ of cases, skin infiltration can occur before bone marrow or peripheral blood involvement in the absence of systemic symptoms. This is known as "aleukaemic LC" or "primary extra-medullary leukaemia" and occurs predominantly with AML and very rarely in ALL. Aleukaemic leukaemia cutis lesions are usually widespread and papulonodular ${ }^{7,8}$. Up to $30 \%$ of children with congenital leukaemia have skin infiltration, and this is one cause of the "blue berry muffin" appearance ${ }^{9}$. Most paediatric patients with LC have high leukaemic tumour load and hepatosplenomegaly ${ }^{10}$.

Diagnosis of LC is based on the morphologic pattern of skin infiltration, cytologic features and the immunophenotypic characteristic of tumour cells. Correlation with clinical data, bone marrow and peripheral blood findings is often helpful to confirm diagnosis ${ }^{11}$. LC is a local manifestation of an underlying systemic disease and treatment is aimed at eradicating systemic disease by using systemic chemotherapy as well as local therapy ${ }^{12}$. In general, development of LC has a poor prognosis. Patients with congenital leukaemia seem to be an exception because LC does not confer a worse prognosis in this clinical setting. Our patient represents a type of leukaemia cutis of acute lymphoblastic leukaemia.

\section{References}

1. Weedon D. Cutaneous infiltrates: lymphomatous and leukaemic. Skin Pathology. 2nd ed. New York: Churchill Livingstone; 2002:1118-20.

2. Brunning RD, Matutes E, Flandria F, et al. In: Jaffe ES, Harris NL, Stein $\mathrm{H}$, et al, editors. World Health Organization
Classification of Tumours: Pathology and Genetics of Tumours of Haematopoietic and Lymphoid Tissues. Lyon, France: IARC Press; 2001:104-5.

3. Agis H, Weltermann A, Fonatsch C, et al. A comparative study on demographic, hematological, and cytogenetic findings and prognosis in acute myeloid leukemia with and without leukemia cutis. Annals of Hematology 2002; 81:90-5. http://dx.doi.org/10.1007/s00277-001-04129

PMid: 11907789

4. Zhang IH, Zane LT, Braun BS, et al. Congenital leukaemia cutis with subsequent development of leukaemia. Journal of the American Academy of Dermatology 2006; 54(2 suppl.):S22-S27. http://dx.doi.org/10.1016/j.jaad.2005.04.038 PMid: 16427986

5. Resnik KS, Brod BB. Leukaemia cutis in congenital leukaemia: analysis and review of the world literature with report of an additional case. Archives of Dermatology 1993; 129:1301-6.

http://dx.doi.org/10.1001/archderm.1993.01

680310071012

6. Cho-Vega JH, Medeiros LJ, Prieto VG, Vega F. Leukaemia cutis. American Journal of Clinical Pathology 2008; 129 (1):130-42. http://dx.doi.org/10.1309/WYACYWF6NG M3WBRT

PMid: 18089498

7. Appelbaum FR, Rowe JM, Radich J, et al. Acute myeloid leukaemia. Hematology Am Soc Hematol Educ Program 2001:62-86. http://dx.doi.org/10.1182/asheducation2001.1 .62

8. Greer JP, Baer MR, Kinney MC. Acute myeloid leukaemia in adults. In: Greer JP, Foerster J, Lukens JN, et al, eds. Wintrobe's Clinical Hematology. Philadelphia, PA: Lippincott Williams \& Wilkins; 2003:2097142. 
9. Resnik KS, Brod BB. Leukaemia cutis in congenital leukaemia analysis and review of the world literature with report of an additional case. Archives of Dermatology 1993; 129: 1301-6.

http://dx.doi.org/10.1001/archderm.1993.01

680310071012

10. Magro CM, Morrison CD, Heerema N, et al. T-cell prolymphocytic leukaemia: an aggressive $\mathrm{T}$ cell malignancy with frequent cutaneous tropism. Journal of the American Academy of Dermatology 2006; 55:467-77. http://dx.doi.org/10.1016/j.jaad.2006.04.060

PMid: 16908353
11. Boccara O, Laloum-Grynberg E, Jeudy G, Aubriot-Lorton MH, Vabres P, de Prost Y, Pacquement $\mathrm{H}$, Brousse N, Fraitag S, Bodemer C. Cutaneous B-cell lymphoblastic lymphoma in children: a rare diagnosis. Journal of the American Academy of Dermatology 2012; 66:51- 7.

http://dx.doi.org/10.1016/j.jaad.2010.10.040

PMid: 21745698

12. Kahwash SB, Qualman SJ. Cutaneous lymphoblastic lymphoma in children: report of six cases with precursor B-cell lineage. Pediatr Dev Pathol 2002; 5:45-53. http://dx.doi.org/10.1007/s10024-001-01044 